\title{
Rhizobakteri İzolatlarının Kırmızı Biberin (Capsicum annuum L.) Verim ve Bitkisel Özellikleri Üzerine Etkileri
}

\section{Ümran TELEK ${ }^{1}$ (D) İran Ersin AKINCI $^{1^{\infty}}$ (D) , Mustafa KÜSEK ${ }^{2}$ (D)}

${ }^{1}$ Kahramanmaraş Sütçü İmam Üniv. Ziraat Fakültesi Bahçe Bitkileri Bölümü, Kahramanmaraş, ${ }^{2}$ Kahramanmaraş Sütçü İmam Üniv. Ziraat Fakültesi Bitki Koruma Bölümü, Kahramanmaras

$\varangle$ : akinci.ie@ksu.edu.tr

\section{ÖZET}

Bu çalışmada Kahramanmaraş baharatlık kırmızı biber alanlarından izole edilen 10 farklı rhizobakteri izolatının; kırmızı biberin (Capsicum annuum L.) verim ve bitkisel özellikleri üzerine etkileri incelenmiştir. Kırmızı ve toplam meyve veriminde en iyi değerler ZHA246 (\%77.01 ve \% 61.50 artışla) ve ZHA017 (\%70.03 ve \%57.12 artışla) bakteri izolatlarından elde edilmiştir. Toplam meyve sayısında $\% 74.15, \% 71.16, \% 65.75$ ve $\% 64.86$ artışla sırasıyla ZHA215, ZHA090, ZHA235 ve ZHA017 daha iyi bulunmuştur. Bitkisel özelliklerden kök yaş ağırlığında ZHA287 ve ZHA246; bitki boyunda ZHA246, ZHA215, ZHA017 ve ZHA090; sürgün yaş ve kuru ağırlığında ZHA246 ve ZHA017; yaprak sayısında, yaprak yaş ağırlığında ve yaprak kuru ağırlığında ZHA246; yaprak eninde ZHA191 rhizobakterileri en iyi uygulamalar olmuşlardır. Rhizobakterilerin, kontrollere göre meyve tohum yaş ağırlığı, meyve tohum kuru ağırlığı, meyve eti yaş ağırlığı, meyve eti kuru ağırlığı, meyve yaş ağırlığı ve kök boyu dışındaki özellikler üzerine etkileri olumlu bulunmuştur. Yapılan Temel Bileşenler Analiziyle (TBA) ZHA246 ve ZHA017, kırmızı biberde verim ve bitkisel özellikleri artırmada en uygun rhizobakteriler olarak belirlenmiştir. ZHA235'te dikkate değer diğer rhizobakteri olmuştur.

\author{
Makale Tarihçesi \\ Geliş Tarihi: 30.07 .2018 \\ Kabul Tarihi: 10.09 .2018 \\ Anahtar Kelimeler \\ Bitki büyümeyi teşvik edici \\ bakteriler, \\ kırmızı biber, \\ verim, \\ bitkisel özellikler
}

Araştırma Makalesi

\section{The Effects of Rhizobacteria Strains on Yield and Plant Characteristics of Red Hot Pepper (Capsicum annuum L.)}

\begin{abstract}
In this study, the effects of 10 different rhizobacteria strains extracted from Kahramanmaras red spice pepper fields were investigated on yield and plant characteristics of red-hot pepper (Capsicum annuum L.). The best values were obtained from ZHA246 (with \%77.01 and $\% 61.50$ increase) and ZHA017 (with \%70.03 and \%57.12 increase) rhizobacteria in red and total fruit yield. ZHA215, ZHA090, ZHA235 and ZHA017 were more found with increase \%74.15, \%71.16, \%65.75 and \%64.86 in total fruit number, respectively. In terms of plant characteristics, the best applications were ZHA287 and ZHA246 in root wet weight; ZHA246, ZHA215, ZHA017 and ZHA090 in plant height; ZHA246 and ZHA017 in stem wet and dry weight; ZHA246 in the number of leaves and leaves fresh and dry weight; ZHA191 in leaves width. According to the controls, the effects of rhizobacteria were found favorable on such characteristics as fruit seeds fresh weight, fruit seeds dry weight, and fruit flesh fresh weight, fruit flesh dry weight, fruits wet weight and root length. ZHA246 and ZHA017 were determined to be the most suitable rhizobacteria for improvement of yield and plant characteristics of red pepper according to Principal Component Analysis (PCA). ZHA235 was another considerable rhizobacterium.
\end{abstract}

\author{
Article History \\ Received : 30.07.2018 \\ Accepted : 10.09.2018
}

Keywords
Plant Growth Promoting
Rhizobacteria,
Red pepper,
Yield,
Plant characteristics

Research Article

To cite: Telek Ü, Akıncı İE, Küsek M 2019. Rhizobakteri İzolatlarının Kırmızı Biberin (Capsicum annuum L.) Verim ve Bitkisel Özellikleri Üzerine Etkileri. KSÜ Tar Doğa Derg 22(1) : 62-70, DOI: 10.18016/ksutarimdoga.vi.448536 


\section{GİRIŞ}

Dünyada yirminci yüzyılın ikinci yarısında artan hızlı nüfusa karşı, yoğun girdi kullanılarak mevcut alanlardan daha fazla verim elde etmek ve tarım dışı alanların açılmasına yönelik politikalar geliştirilmiştir. Ancak bu amaç için fazla ve yanlış tarım ilaç-gübre uygulamaları toprak özelliklerinin bozulmasına, verimliliğinin yitirilmesine, besin maddesi içeriklerinin azalmasına, tuzlanmasına ve çoraklaşmasına neden olmaktadır (Aksoy, 1999).

Gübre kullanımı ve fazla kimyasal uygulaması ile meydana gelen olumsuzlukları ortadan kaldırmak ve zararları gidermek amacıyla yapılan çalışmalar neticesinde, biyolojik gübre ve biyolojik savaş elemanı olarak kullanılabilen mikroorganizmalar ön plana çıkmaktadır. $\mathrm{Bu}$ amaçla son zamanlarda gündeme gelen en önemli mikroorganizmalar bakterilerdir (Higa ve Paar, 1994).

Toprak içerisinde birbirinden farklı özelliklere sahip çok sayıda mikroorganizmalar yaşamaktadır. Mikroorganizma birlikleri içerisinde bitki kökleri ile bağlantı kuran bakterilere kök bakterileri denir (Romerio, 2000). Bitkiye faydası bulunan kök bakterileri için bitki gelişimini teşvik eden kök bakterileri (Plant Growth Promoting Rhizobacteria: PGPR) denilmektedir. PGPR terimi ilk defa 1978 yılında ifade edilmiştir (Kleopper ve Schroth, 1978).

Mikroorganizmaların PGPR olarak değeri artmakta ve hızla ticarileşmektedir. PGPR preperatlarının üretilmesinde doğadaki bakterilerin izole edilmesi yoluna gidilmekte, farklı bakterilerin farklı özelliklerinden yararlanılmaya çalışılmaktadır. Bu özellikler; yüksek rizosfer yeteneğinin bulunması, yüksek rekabette saprofit yeteneğinin olması, bitki gelişimini olumlu yönde etkilemesi, kütlesini kolayca arttırabilmesi, geniş hareket yeteneğinin olması, mükemmel ve güvenilir kontrol gücüne sahip olması, çevreye karşı güvenli olması, diğer kök bakterileri ile uyum içinde yaşaması, kuraklık, sıcaklık, okside edici ajanlar ile UV'ye ve radyasyona karşı tolerans göstermesi şeklinde sıralanabilir. Bitki gelişimini uyaran rizobakteriler (PGPR) bu özellikleriyle biyolojik gübre (BG) olarak kullanılmaktadır (Jeyarajan ve Nakkeeran, 2000; Çakmakçı ve ark., 2005; Bayrak ve ark., 2014; İmriz ve ark., 2014).

PGPR'lerin etkileri bölgeye, ekolojiye ve özellikle türlere göre değişmekte; herhangi bir bölgede özellikle endüstriyel değeri yüksek türlerin verimliliğini veya toprak-beslenme ile ilgili sorunları gidermede önemi daha da artmaktadır. Bu durum her bölgeye ve türe uyumlu PGPR'lerin tespit edilmesi ve kullanımina ilişkin araştırmalara ihtiyaç olduğunu ortaya koymaktadır. Ülkemizin önemli endüstriyel ürünlerinden birisi olan ve ilin adı ile özdeşleşmiş Kahramanmaraş baharatlık kırmızı biberi için de benzer çalışmalara ihtiyaç bulunmaktadır.
Bu çalışmada daha önce Kahramanmaraş kırmızı biber alanlarından elde edilen ve PGPR şeklinde kullanılmaya aday 10 farkl rhizobakteri izolatının, Kahramanmaraş kırmızı biberinin verim ve bitkisel özellikler üzerine etkilerinin incelenmesi, olası ticari kullanım potansiyellerinin ortaya konulması ve kırmızı biber üreticilerine katkı sunulması amaçlanmıştır.

\section{MATERYAL ve METOT}

Araştırma 2015-2016 yılları arasında KSÜ. Ziraat Fakültesi, Bahçe Bitkileri ve Bitki Koruma Bölümü deneme alanları ile laboratuvarlarında gerçekleştirilmiştir. Bitkisel materyal olarak baharatlık kırmızı biber (Capsicum annuum L.) çeşidi olan Sena kullanılmıştır.

\section{Bitkilerin Yetiştirilmesi ve Kültürel İşlemler}

Denemeye Sena çeşidi biber bitkilerinin elde edilmesi ile başlanmıştır. Çeşide ait biber tohumları, içerisinde elenmiş kırmızı bahçe toprağı ve çiftlik gübresi (3:1) bulunan $5 \mathrm{~cm}$ çaplı (yaklaşık $150 \mathrm{~cm}^{3}$ ) ve 45 bölmeli viyollere 27.03.2016 tarihinde ekilerek fide haline gelmeleri beklenmiştir. Fideler 3-4 gerçek yapraklı ve $15-20 \mathrm{~cm}$ boya geldikleri 15.07.2016 tarihinde asıl yerleri olan $25 \times 25 \times 80 \mathrm{~cm}$ boyutlarında, yine içerisinde elenmiş kırmızı bahçe toprağı ve çiftlik gübresi (3:1) bulunan saksılara dikilmişlerdir. Denemeler kırmızı biberin endüstriyel ürün olması nedeniyle açık tarla koşullarında yürütülmüştür.

Fidelerin tüm çıkış, fide ve dikim sonrası kültür işlemlerinde Eşiyok (2012)'a göre hareket edilmiştir. Deneme boyunca herhangi ciddi bir hastalık ve zararlı ile karşlaşılmamış; bitki koruma işlemlerine başvurulmamıştır. Çalışma son hasadın yapıldığı ve bitkisel özelliklerin elde edilmesi amacıyla sökümlerin yapıldığı 02.11.2016 tarihinde son verilmiştir.

Denemede Kullanılan Bakteriler, Solüsyonlarının Hazırlanması ve Uygulanması

Araştırmaya konu olan PGPR'lar Kahramanmaras bölgesinde yetişen biber bitkilerinin köklerinden izole edilmiştir. İzole edilen ZHA017, ZHA090, ZHA191, ZHA212, ZHA215, ZHA235, ZHA246, ZHA287, ZHA308, ZHA579 bakterileri KSÜ, Ziraat Fakültesi, Bitki Koruma Bölümü mikroorganizma kültür koleksiyonundan (\%15 gliserolde ve $-20^{\circ} \mathrm{C}$ 'de muhafaza edilen) alınmıştır (Çizelge 1). İzolatların geliştirilmesi için Nutrient Broth sıvı besi ortamı içerisine alınmış ve Nutrient Agar katı besi ortamı içeren Petri kaplarına çizgi ekim yapılmıştır.

Ekim yapılan petriler $25^{\circ} \mathrm{C}$ 'de 24 saat inkübe edilmiştir. Bakteri uygulamasında fizyolojik su $(8.5 \mathrm{~g} / \mathrm{l}$ $\mathrm{NaCl})$ ile süspansiyonları hazırlanmış ve turbidimeter ile $\% 60$ (1010 hücre/ml) olarak ayarlanmıştır.

Denemede kullanılan bu 10 bakteri izolatının kırmızı biberin bitkisel özellikleri, verim ve meyve kalitesine 
etkileri; denemeye eklenen EMA PLUS Mikrobiyal Gübre (Pseudomanas spp., Rhizobium spp., Azotobacter spp., Bacillus spp., Serratia spp., Aspergillus spp., Penicillium spp.; $100 \mathrm{ml}$ fizyolojik su içerisine $3 \mathrm{ml}$ eklenerek hazırlanmış) ve kontrol (bakteri izolatı kullanılmayan) uygulamaları ile karşılaştırılarak ortaya konulmaya çalışılmıştır
(Çizelge 1). Solüsyonlar (10 bakteri izolatına ait çözelti, EMA PLUS mikrobiyal gübre ve kontrol çözeltisi ( $8.5 \mathrm{~g} / \mathrm{l} \mathrm{NaCl}$ içerikli fizyolojik su)) içerisine biber fidelerinin köklerinin daldırılarak 10 dakika süreyle bekletildikten sonra asıl yerlerine dikilmesi şeklinde uygulanmıştır.

Çizelge 1. Denemede kullanılan PGPR türleri

\begin{tabular}{cc|cc}
\hline \multicolumn{1}{c}{ İzolat } & PGPR & İzolat & PGPR \\
\hline ZHA017 & Belirlenmemiş & ZHA246 & Belirlenmemiş \\
ZHA090 & Bacillus pumilus & ZHA287 & Bacillus subtilis ss subtilis \\
ZHA191 & Pseudomonas fluorescens & ZHA308 & Pseudomonas viridilivida \\
ZHA212 & Paenibacillus castaneae & ZHA579 & Belirlenmemiş \\
ZHA215 & Paenibacillus castaneae & Ema Plus & Mikrobiyal gübre \\
ZHA235 & Belirlenmemiş & Kontrol & Bakterisiz \\
\hline
\end{tabular}

Deneme Tesadüf Parselleri Deneme Desenine göre 3 tekerrürlü olarak kurulmuştur. Her tekerrürde kullanılan saksı sayısı 4 adet ve her saksıda 3 adet olmak üzere toplam biber bitkisi sayısı 12 adet olmuştur. Deneme boyunca bazı bitkilerde ölümler gerçekleşmiş, kalan bitki sayıları üzerinden değerlendirmeler yapılmıştır.

Deneme sonunda, bitkiler sökülmüş, önce çeşme suyu ve ardından saf su ile yıkanmış, sularını çekinceye kadar bekletilmişler; daha sonra kök, sürgün ve yaprakları ayrılmıştır. Bakterilerin verim, bitkisel ve meyve özellikleri üzerine etkileri ortaya konulmaya çalışılmıştır.

Araştırma sonuçları varyans analizi (ANOVA) ile istatistiki analize alınmış, ortalamalar arasındaki farklılıklar "Duncan Çoklu Karşılaştırma Testi”" karşılaştırılmıştır. İstatistiki analizlerde SPSS bilgisayar programı kullanılmıştır. Rhizobakterilerin tüm incelenen özellikler ele alınarak birbirlerinden farklılık gösterenleri ve ticari kullanım potansiyeli olanları belirlemek üzere, Temel Bileşenler Analizi yönteminden faydalanılmıştır (Anonim, 2017).

\section{BULGULAR VE TARTIŞMA \\ Verim}

Farklı rhizobakteri izolatları ile EMA PLUS ticari preparat ve bakteri kullanılmayan kontrol uygulamalarının kırmızı biberde verim üzerine etkisinin belirlendiği bu çalışmada istatistiki olarak yeşil meyve verimi üzerine $\mathrm{p} \leq 0.05$; kırmızı ve toplam meyve verimi üzerine ise $\mathrm{p} \leq 0.01$ düzeyinde önemli farklılıkların olduğu bulunmuştur (Çizelge 2).

Çizelge 2. Rhizobakteri izolatlarının kırmızı biberin verimi üzerine etkisi

\begin{tabular}{|c|c|c|c|c|c|c|}
\hline \multirow{2}{*}{$\begin{array}{c}\text { Rhizobakteri } \\
\text { İzolatları }\end{array}$} & \multicolumn{2}{|c|}{ Yeşil Meyve Verimi } & \multicolumn{2}{|c|}{ Kırmızı Meyve Verimi } & \multicolumn{2}{|c|}{ Toplam Meyve Verimi } \\
\hline & (g/bitki)* & $\%$ & $(\mathrm{~g} / \mathrm{bitki}) * *$ & $\%$ & $(\mathrm{~g} / \mathrm{bitki}) * *$ & $\%$ \\
\hline ZHA246 & $208.64 \mathrm{abc}$ & 40.06 & $364.38 \mathrm{a}$ & 77.01 & $573.02 \mathrm{a}$ & 61.50 \\
\hline ZHA017 & $207.47 \mathrm{abc}$ & 39.27 & $350.01 \mathrm{a}$ & 70.03 & $557.48 \mathrm{a}$ & 57.12 \\
\hline ZHA215 & $287.04 \mathrm{a}$ & 92.70 & $260.73 \mathrm{abc}$ & 26.66 & $547.77 \mathrm{a}$ & 54.38 \\
\hline ZHA090 & $228.33 \mathrm{ab}$ & 53.28 & $312.23 \mathrm{abc}$ & 51.67 & $540.56 \mathrm{a}$ & 52.35 \\
\hline ZHA235 & $183.37 \mathrm{abc}$ & 23.10 & $326.81 \mathrm{ab}$ & 58.76 & $510.13 \mathrm{a}$ & 43.77 \\
\hline ZHA579 & $152.21 \mathrm{bc}$ & 2.18 & $324.24 \mathrm{ab}$ & 57.51 & $476.45 \mathrm{a}$ & 34.28 \\
\hline ZHA287 & $190.41 \mathrm{abc}$ & 27.82 & $272.81 \mathrm{abc}$ & 32.52 & $463.22 \mathrm{a}$ & 30.55 \\
\hline ZHA212 & $189.82 \mathrm{abc}$ & 27.43 & $262.87 \mathrm{abc}$ & 27.70 & $452.69 \mathrm{ab}$ & 27.58 \\
\hline ZHA308 & $110.66 \mathrm{bc}$ & -25.71 & $252.65 \mathrm{abc}$ & 22.73 & 363.31abc & 2.39 \\
\hline ZHA191 & $98.57 \mathrm{bc}$ & -33.82 & $141.31 \mathrm{c}$ & -31.35 & $239.80 \mathrm{c}$ & -32.41 \\
\hline KONTROL & $148.96 \mathrm{bc}$ & - & $205.85 \mathrm{abc}$ & - & $354.81 \mathrm{abc}$ & \\
\hline EMA PLUS & $89.20 \mathrm{c}$ & 40.11 & $161.02 \mathrm{bc}$ & 21.77 & $250.22 \mathrm{bc}$ & 29.47 \\
\hline
\end{tabular}

$=\mathrm{p} \leq 0.05$ 'de ve $* *=\mathrm{p} \leq 0.01$ 'de önemli; öd =önemli değil; “\%” değerler kontrole göre farktır.

Farklı harfler ile gösterilen ortalamalar, Duncan Çoklu Karş̧laştırma Testi'ne göre $\mathrm{p} \leq 0.05$ 'de önemlidir.

Çizelge 2'de rhizobakterilerin yeşil meyve verimi üzerine en yüksek etkinin \%92.70 artış ile ZHA215 izolatından elde edildiği anlaşılmaktadır. $\mathrm{Bu}$ uygulamayı ZHA090 izolatı \%53.28 artış ile izlemiştir. Aynı istatistiki gruba giren ZHA246, ZHA017, ZGHA287, ZHA212 ve ZHA235 sirasiyla \%40.6, $\% 39.27, \% 27.82, \% 27.43$ ve $\% 23.10$ artış ile diğer dikkat çeken uygulamalar olmuşlardır. Yeşil meyve verimi en düşük uygulama \%40.11 artış ile EMA PLUS olmuştur. Kırmızı meyve verimine bakıldığında en yüksek verimin \%77.01 artış ile ZHA246 ve aynı istatistiki grupta yer alan \%70.03 artış ile ZHA017 izolatlarında olduğu belirlenmiştir. 
$\mathrm{Bu}$ uygulamaların ardından gelen \%58.76 artış ile ZHA235 ve \%57.51 artış ile ZHA579 diğer önemli uygulamaları oluşturmuşlardır. Kırmızı meyve veriminin en düşük olduğu uygulama \%-31.35 ile ZHA191 olmuştur. Diğer uygulamalar ise farklı istatistiki gruplarda yer alarak ortadaki sıralara yerleşmişlerdir. Toplam meyve veriminde en yüksek verimi aynı grupta yer alan ZHA246, ZHA017, ZHA215, ZHA090, ZHA235, ZHA579 ve ZHA287 uygulamaları vermiştir. $\mathrm{Bu}$ özellik için ZHA212 uygulaması diğer dikkat çeken uygulama olmuştur. Diğer uygulamalar ise azalan verim değerleri ile sonraki sıralarda yer bulmuşlardır. Yeşil, kırmızı ve toplam meyve verimlerinin hiç bakteri kullanılmayan ve EMA PLUS kullanılan biber bitkilerinden elde edilen verimlere göre rhizobakteri kullanılmasıyla arttığı belirlenmiştir. Rhizobakteri kullanımı ile verimin arttığına yönelik daha önce yapılmış çalışmalara göre bitki verimi üzerine PGPR'lerin olumlu etkileri pek çok araştırıcı tarafından gözlemlenmiş ve çalışmamızı destekler bulgular rapor edilmiştir. Çilekte yapılan bir çalışmada yararlı kök bakterisi kullanımı ile verimin \%1.98 ile \%20.85 arasındaki değişimle artış sağlanabildiği rapor edilmektedir (Ertürk ve ark., 2012). Başka bir araştırmada da, PGPR'lerin kullanımı nohut ve bezelyede kuru dane veriminde artışa neden olmuştur.

Nohut denemesinde bakteriler kontroldan farklı olarak 7 grup oluşturmuşlar, içlerinden kontrole göre sağladığı yaklaşık 5 kat artışla 33 numaralı bakteri dikkat çekmiştir. Bezelyede ise tek bir bakteri (15 numaralı) kontrole göre verimi 2.5 kat artırmıştır (Uslu, 2006).

\section{Meyve Sayısı}

Çalışmada farklı rhizobakteriler ile EMA PLUS ve kontrol (bakteri kullanılmayan) uygulamalarının verimin diğer bir göstergesi olan yeşil meyve sayısı için $\mathrm{p} \leq 0.05$ ve kırmızı meyve sayısı için $\mathrm{p} \leq 0.01$ düzeyinde önemli olduğu; ancak toplam meyve sayısı için etkili olmadığı görülmüştür (Çizelge 3).

Çizelge 3. Rhizobakteri izolatlarının kırmızı biberde meyve sayısı üzerine etkisi

\begin{tabular}{|c|c|c|c|c|c|c|}
\hline \multirow{2}{*}{$\begin{array}{c}\text { Rhizobakteri } \\
\text { İzolatları }\end{array}$} & \multicolumn{2}{|c|}{ Yeşil Meyve Sayısı } & \multicolumn{2}{|c|}{ Kırmızı Meyve Sayısı } & \multicolumn{2}{|c|}{ Toplam Meyve Sayısı } \\
\hline & $($ adet/bitki) $* *$ & $\%$ & $($ adet/bitki)** & $\%$ & $($ adet/bitki)*** & $\%$ \\
\hline ZHA215 & $41.66 \mathrm{a}$ & 108.3 & $23.00 \mathrm{abc}$ & 35.29 & $64.66 \mathrm{a}$ & 74.75 \\
\hline ZHA090 & $32.00 \mathrm{ab}$ & 60.0 & $31.33 \mathrm{ab}$ & 84.29 & $63.33 \mathrm{a}$ & 71.16 \\
\hline ZHA235 & $26.66 \mathrm{ab}$ & 33.3 & $34.66 \mathrm{a}$ & 103.88 & $61.33 \mathrm{a}$ & 65.75 \\
\hline ZHA017 & $28.66 \mathrm{ab}$ & 43.3 & $32.33 \mathrm{a}$ & 90.17 & $61.00 \mathrm{a}$ & 64.86 \\
\hline ZHA246 & $27.33 \mathrm{ab}$ & 36.7 & $31.00 \mathrm{ab}$ & 82.35 & $58.33 \mathrm{ab}$ & 57.64 \\
\hline ZHA287 & $30.00 \mathrm{ab}$ & 50.0 & $24.33 \mathrm{abc}$ & 43.11 & $54.33 \mathrm{ab}$ & 46.83 \\
\hline ZHA212 & $25.66 \mathrm{ab}$ & 28.3 & $25.66 \mathrm{abc}$ & 50.94 & $51.33 \mathrm{ab}$ & 38.72 \\
\hline ZHA579 & $21.33 \mathrm{~b}$ & 6.63 & $30.00 \mathrm{ab}$ & 76.47 & $51.33 \mathrm{ab}$ & 38.72 \\
\hline ZHA308 & $18.66 \mathrm{~b}$ & -6.7 & $24.33 \mathrm{abc}$ & 43.11 & $43.00 \mathrm{abc}$ & 16.21 \\
\hline ZHA191 & $14.66 \mathrm{~b}$ & -26.7 & $11.66 \mathrm{c}$ & -31.41 & $26.33 \mathrm{c}$ & -28.83 \\
\hline KONTROL & $20.00 \mathrm{~b}$ & - & $17.00 \mathrm{bc}$ & - & $37.00 \mathrm{bc}$ & - \\
\hline EMA PLUS & $16.00 \mathrm{~b}$ & 20.0 & $12.33 \mathrm{c}$ & 27.47 & $28.33 \mathrm{c}$ & 23.43 \\
\hline
\end{tabular}

$=\mathrm{p} \leq 0.05$ 'de ve $* *=\mathrm{p} \leq 0.01$ 'de önemli; öd =önemli değil; “\%” değerler kontrole göre farktır.

Farklı harfler ile gösterilen ortalamalar, Duncan Çoklu Karşılaştırma Testi’ne göre $\mathrm{p} \leq 0.05$ 'de önemlidir.

Çizelge 3’ten izleneceği üzere yeşil meyve sayısı bakımından en fazla meyve \% 108.3 artış ile ZHA215 izolatından elde edilmiştir. $\mathrm{Bu}$ uygulamayı aynı istatistik grubun birer üyesi olan $\% 60.0$ artış ile ZHA090, \%50.0 artış ile ZHA287, \%43.3 artış ile ZHA017, \%36.7 artış ile ZHA246, \%33.3 artış ile ZHA235 ve \%28.3 artış ile ZHA212 diğer üstün uygulamalar olmuşlardır. Kırmızı meyve sayısında \%103.88 artış ile ZHA235 izolatı ve \%90.17 artış ile ZHA017 izolatı en başarılı uygulamalar olarak saptanmıştır. ZHA090, ZHA246 ve ZHA579 sırasıyla $\% 84.29, \% 82.35$ ve $\% 76.47$ artış değerleriyle ile diğer önem arz eden izolatlar olmuşlardır. En fazla toplam meyve sayısına sirasıyla ZHA215 (\%74.75 artış),
ZHA090 (\%71.16 artıs), ZHA235 (\%65.75 artıs), ZHA017 (\%64.86 artış) rhizobakteri izolatlarında ulaşılmıştır. Yapılan çalışmada özellikle kırmızı ve toplam meyve sayısı üzerinden gidildiğinde ZHA308 ve ZHA191 dışında kullanılan rhizobakterilerden; EMA PLUS ve hiç bakteri kullanmayan kontrol uygulamasına göre daha başarılı sonuçlar elde edildiğini göstermiştir. Benzer sonuçlara açık tarla koşullarında domates ve biber meyve sayısında yararlı rhizobakterlerden Trichoderma harzianum T22 ve Trichoderma atroviride P1 izotlarının kullanılmış olduğu çalışmalara ulaşılmış; yararlı bakteri kullanımının meyve sayısını arttırdığı doğrulanmıştır. Öyle ki Trichoderma harzianum uygulanmış alanlarda 
kontrol uygulamalarina göre biber ve domateste, meyve sayısının üç katına kadar aratabileceği belirlenmiştir (Vinale ve ark., 2006) İçeriğinde Frateuria aurantia bulunan biyolojik bir gübre olan Symbion-K kodlu gübrenin sera domates yetiştiriciliğinde farklı dozlardaki etkileri incelenmiş ve meyve sayısı üzerine olumlu etkileri görülmüştür (Öztekin ve ark., 2015). Araştırmada; materyal olarak Akçin-91 nohut çeşidi tohumları, inokulant olarak da Rhizobium ciceri tercih edilmiştir. Tohuma aşılama çalışmasında; nodüller daha büyük ve ana köke yakın oluşurken, kök ağırlığında da artış görülmüştür. Bitki boyu, bitki ağırlığı, bitkide meyve sayısı, tane ağırlığı ve verim yönünden toprağa aşılama yöntemiyle yakın veriler alınmış, artan azot dozlarında bu özelliklerin de olumlu yönde değiştiği gözlenmiştir (Meral ve ark., 1998).

\section{Meyve Özellikleri}

Kontrol uygulamaları ile karşılaştırılmalı kurulan araştırmada farklı rhizobakteri izolatlarının meyve çekirdek yaş ve kuru ağırlığı, meyve eti yaş ve kuru ağırlığı, meyve toplam yaş ağırlığı üzerine etkileri istatistiki anlamda önem arz etmezken; meyve toplam kuru ağırlığı üzerine etkisi $\mathrm{p} \leq 0.05$ seviyesinde etkili olduğu görülmüştür (Çizelge 4).

Cizelge 4. Rhizobakteri izolatlarının kırmızı biberde meyve özellikleri üzerine etkisi

\begin{tabular}{|c|c|c|c|c|c|c|c|c|c|c|c|c|}
\hline \multirow{2}{*}{$\begin{array}{c}\text { Rhizobakteri } \\
\text { İzolatları }\end{array}$} & \multicolumn{2}{|c|}{$\begin{array}{l}\text { Tohum Yaş } \\
\text { Ağırlığı }\end{array}$} & \multicolumn{2}{|c|}{$\begin{array}{l}\text { Tohum Kuru } \\
\text { Ağgrlığı }\end{array}$} & \multicolumn{2}{|c|}{$\begin{array}{l}\text { Meyve Eti } \\
\text { Yaş Ağırlığı }\end{array}$} & \multicolumn{2}{|c|}{$\begin{array}{l}\text { Meyve Eti Kuru } \\
\text { Ağgrlığı }\end{array}$} & \multicolumn{2}{|c|}{$\begin{array}{l}\text { Meyve Yaş } \\
\text { Ağ̣rlığı }\end{array}$} & \multicolumn{2}{|c|}{$\begin{array}{l}\text { Meyve Kuru } \\
\text { Ağırlığı }\end{array}$} \\
\hline & (g)öd & $\%$ & (g)öd & $\%$ & (g)öd & $\%$ & (g)öd & $\%$ & (g)öd & $\%$ & $(\mathrm{~g})^{*}$ & $\%$ \\
\hline ZHA287 & 2.25 & 19.68 & 0.75 & 10.29 & 9.21 & 0.87 & 1.32 & 1.53 & 11.45 & 3.99 & $2.07 \mathrm{a}$ & 4.54 \\
\hline ZHA & 2.26 & 20.21 & 0.82 & 20.58 & 8.39 & -8.10 & 1.26 & -3.07 & 10.65 & -3.26 & $2.07 \mathrm{a}$ & 4.54 \\
\hline ZHA & 2.15 & 14.36 & 0.78 & 14.70 & 8.35 & -8.54 & 1.20 & -7.69 & 10.50 & -4.63 & $1.97 \mathrm{ab}$ & -0.50 \\
\hline ZHAO & 1.89 & 0.50 & 0.78 & 14.70 & 8.57 & -6.13 & 1.16 & -10.76 & 10.45 & -5.08 & 1.94 & -2.02 \\
\hline ZHA212 & 2.07 & 10.10 & 0.74 & 8.82 & 7.92 & -13.25 & 1.20 & -7.69 & 9.99 & -9.26 & 1.93ab & -2.52 \\
\hline & 2.19 & 16.48 & 0.69 & 1.47 & 8.77 & -3.94 & 1.25 & -3.84 & 10.9 & -0.45 & & -2.52 \\
\hline & 1.92 & 2.12 & 0.73 & 7.35 & 7.22 & -20.92 & 1.19 & -8.46 & 9.14 & -16.98 & 1.91 & -3.53 \\
\hline ZHA246 & 1.97 & 4.78 & 0.82 & 20.58 & 8.80 & -3.61 & 1.09 & -16.15 & 10.77 & -2.17 & $1.90 \mathrm{ab}$ & -4.04 \\
\hline ZHA017 & 1.84 & -2.12 & 0.65 & -4.41 & 8.20 & -10.18 & 1.19 & -8.46 & 10.04 & -8.81 & $1.83 \mathrm{ab}$ & -7.57 \\
\hline & 2.13 & 13.29 & 0.69 & 1.47 & 8.24 & -9.74 & 1.14 & -12.30 & 10.38 & -5.72 & 1.82 & -8.08 \\
\hline KONTROL & 1.88 & - & 0.68 & - & 9.13 & - & 1.30 & - & 11.01 & - & $1.98 \mathrm{ab}$ & - \\
\hline EMA PLUS & 1.73 & 7.97 & 0.62 & 8.82 & 7.56 & 17.19 & 0.97 & 25.38 & 9.29 & 15.62 & $1.59 \mathrm{~b}$ & 19.69 \\
\hline
\end{tabular}

$=\mathrm{p} \leq 0.05$ 'de ve $* *=\mathrm{p} \leq 0.01$ 'de önemli; öd =önemli değil; “\%” değerler kontrole göre farktır.

Farklı harfler ile gösterilen ortalamalar, Duncan Çoklu Karşılaştırma Testi’ne göre $\mathrm{p} \leq 0.05$ 'de önemlidir.

Çizelge 4 incelendiğinde her ne kadar meyve özelliklerinden çekirdek yaş ve kuru ağırlıklarıyla et yaş ve kuru ağırlıkları istatistiki olarak önemli bulunmasa da; çekirdek yaş ağırlığında ZHA579, ZHA287 ve ZHA215'in sirasiyla \%20.21, \%19.68 ve \%16.48 artış ile; çekirdek kuru ağırlığında ise \%20.58 artış ile ZHA579 ve ZHA246'nın değerleriyle öne çıkan uygulamalar olduğu görülmektedir. Meyve eti yaş ve kuru ağırlığında ZHA287 ve ZHA579 rhizobakteri izolatları, uygulama yapılmayan kontrole yakın değerler vermesine rağmen tüm izolatların içerisinde dikkat çeken ve onlardan daha iyi değerler veren uygulamalar olmuşlardır. Yapılan analizler sonucunda istatistiksel verilere göre toplam meyve yaş ağırlığı önemli olmasa da bu özellikte kontrol dışında araştırma konusu olan uygulamalardan ZHA287, ZHA246 ve ZHA579 başta gelmişlerdir. Nitekim bu elde edilen sonuçlar istatistiki olarak önem arz eden meyve toplam kuru ağırlığı ile daha da anlam kazanmıştır. Meyve toplam kuru ağırlığına bakıldığında en yüksek değerlerin \%4.54 artış ile ZHA287 ve ZHA579 rhizobakterilerinden elde edildiği görülebilmektedir. Benzer bir çalışmada sera domates yetiştiriciliğinde bitki gelişimi, verim ve meyve kalitesi açısından azot tutucu bakterilerin etkilerini incelemek için yapılmıştır. Bitki gelişimine bakıldığında vejetatif ve generatif yaş ve kuru ağırlıkları arasındaki fark istatistiksel olarak etkili görülmemiştir (Öztekin ve ark., 2015). Yapılan bir başka çalışmada biberlerde Xanthomonas axonopodis pv. vesicatoria'nın neden olduğu bakteriyel leke hastalığının biyolojik mücadele yöntemleri araştırılmış ve yapılan araştırmada toprak ve bitki köklerinden elde edilen toplam 118 adet bakteri izolatı tercih edilmiştir. Araştırmacı 11 adet bakteri izolatını aday PGPR izolatı olarak fosfatı indirgemesi bakımından tercih etmiştir. İzolatlar arasından tercih edilen üç tanesi ile yaptığı saksı ve tarla denemelerinde PGPR uygulanan bitkilerde hastalık şiddetinin \%65 oranında azaldığı gözlenmiştir. PGPR'ların bitki boyu, gövde çapı, bitki yaş ağırlı̆̆ı, bitki kuru ağırlığı, kök uzunluğu, kök kuru ağırlığı, verim, meyve boyu ve meyve sayısında olumlu yönde etkili olduğu görülmüştür (Mirik ve ark., 2008).

\section{Kök Gelişimi}

Rhizobakteri izolatlarının biberin kök özellikleri üzerine etkileri kök boyu, yaş ağırlığı ve kuru ağırlığı üzerine kök gelişim analizleri istatistik sonuçları 
Çizelge 5’te verilmiştir. Çizelge 5'e göre istatistiki anlamda kök boyu önemsiz bulunurken; kök yaş ve kuru ağırlıklarının bakteri izolatları uygulamalarından \%5 düzeyinde etkilendiği ortaya çıkmıştır. Rhizobakteri izolatlarının kök boyu üzerine herhangi istatistiksel bir etkisi olmasa da en yüksek kök boyu \%11.98 artış ile ZHA246 uygulamasından elde edilmiş; ZHA212, ZHA090 ve ZHA308 de diğer dikkat çeken uygulamalar olmuştur. Kullanılan rhizobakteriler içerisinde en fazla kök yaş ağırlık $\% 105.80$ artış ile ZHA212, \%89.09 artış ile ZHA246 ve \%88.95 artış ile ZHA287 uygulamalarından alınmıştır.

Çizelge 5. Rhizobakteri izolatlarının kırmızı biberde kök gelişimi üzerine etkisi

\begin{tabular}{|c|c|c|c|c|c|c|}
\hline \multirow{2}{*}{$\begin{array}{l}\text { Rhizobakteri } \\
\text { İzolatları }\end{array}$} & \multicolumn{2}{|c|}{ Kök Boyu } & \multicolumn{2}{|c|}{ Kök Yaş Ağırlığı } & \multicolumn{2}{|c|}{ Kök Kuru Ağırlığı } \\
\hline & $(\mathrm{cm} /$ bitki) öd & $\%$ & (g/bitki)* & $\%$ & (g/bitki)* & $\%$ \\
\hline ZHA287 & 26,44 & 2,56 & $13,34 \mathrm{a}$ & 88,95 & $3,85 \mathrm{a}$ & 49,22 \\
\hline ZHA246 & 28,87 & 11,98 & $13,35 \mathrm{a}$ & 89,09 & $3,72 \mathrm{ab}$ & 44,18 \\
\hline ZHA215 & 25,44 & $-1,31$ & $10,72 \mathrm{ab}$ & 51,84 & $3,34 \mathrm{ab}$ & 29,45 \\
\hline ZHA191 & 25,83 & 0,19 & $9,39 \mathrm{ab}$ & 33 & $3,32 \mathrm{ab}$ & 28,68 \\
\hline ZHA308 & 28,39 & 10,12 & $10,10 \mathrm{ab}$ & 43,05 & $3,31 \mathrm{ab}$ & 28,29 \\
\hline ZHA017 & 27,89 & 8,18 & $11,69 \mathrm{ab}$ & 65,58 & $3,23 \mathrm{ab}$ & 25,19 \\
\hline ZHA090 & 28,45 & 10,35 & $11,19 \mathrm{ab}$ & 58,49 & $3,04 \mathrm{ab}$ & 17,82 \\
\hline ZHA579 & 26,55 & 2,98 & $8,78 \mathrm{ab}$ & 24,36 & $2,86 a b$ & 10,85 \\
\hline ZHA235 & 26,44 & 2,56 & $10,60 \mathrm{ab}$ & 50,14 & $2,80 \mathrm{ab}$ & 8,52 \\
\hline ZHA212 & 28,78 & 11,63 & $14,53 \mathrm{a}$ & 105,8 & $2,72 \mathrm{ab}$ & 5,42 \\
\hline KONTROL & 25,78 & - & $7,06 \mathrm{~b}$ & - & $2,58 \mathrm{~b}$ & - \\
\hline EMA PLUS & 23,55 & 8,65 & $6,84 \mathrm{~b}$ & 3,11 & $2,61 a b$ & 1,16 \\
\hline
\end{tabular}

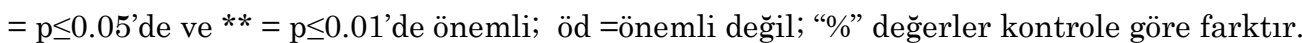

Farklı harfler ile gösterilen ortalamalar, Duncan Çoklu Karşılaştırma Testi’ne göre $\mathrm{p} \leq 0.05$ 'de önemlidir.

Diğer rhizobakteri izolatları farklı bir istatistiki grupta yer alarak bunları izlemiş; tüm izolatların kontrol uygulamalarına göre daha iyi kök yaş ağırlığı oluşumunu sağladıkları tespit edilmiştir. Kök kuru ağırlığı kazanımında en üstün rhizobakteri izolatı olarak \%49.22 artış ile ZHA287 uygulaması olmuştur. Kök kuru ağırlığında EMA PLUS'ın da olduğu diğer tüm rhizobakteri izolatlarının ise bu uygulamayı takip ettiği ve rhizobakteri uygulaması yapılmayan kontrole göre daha iyi sonuç verdikleri belirlenmiştir. Farklı rhizobakteri izolatlarının kök özellikleri üzerine etkilerinin incelendiği bu çalışmada kök boyu üzerine etki belirlenememiş; kök yaş ve kuru ağırlıklarının arttırılmasında rhizobakteri uygulamalarından olumlu sonuçlar alınmıştır. Araştırmadan elde edilen bu sonuçlar; bitkilere uygulanan PGPR izolatlarının kültür bitkilerinde kök sayısı ve kök uzunluğunu artırdığına yönelik denemelere ait bulgularla uyumludur (Khalid ve ark, 2003; Asghar ve ark., 2004). Bu durum yararlı rhizobakterilerin kullanıldığı Origanum majorana L. bitkisinin kök kuru ağırlıklarında, kontrole kıyasla önemli artışlar oluşturduğu sonuçlariyla da destek görmektedir (Banchio ve ark., 2008). Kuraklık stresinin meydana getireceği zararın engellenmesinde veya düşürülmesinde bitkilerde bazı karmaşı ekstraselülar polimerik maddelerin oluşmasının (EPS, Extracellular Polymeric Substances) neden olduğu gözlenmiştir. İncelemeler, PGPR'lerin kullanımı ile bitki kök yüzeyinde biyofilm tabakasının meydana geldiğini göstermektedir (Potts, 1994). Başka bir çalışmada kurak ortamlarda yetiştirilen ayçiçeği fidelerine PGPR uygulamaları ile bitki kök yüzeyinde biyofilm tabakasının oluştuğu araştırılmıştır (Svehya ve ark., 2009). Gerçekleştirilen başka bir araştırmada IAA üreten Pseudomonas putida GR $12-2$ ve Enterobacter cloacae CAL3 ile kanola ve domates bitkilerinin inokulasyonu neticesinde fide köklerinin gelişimi üzerine etkili bir artış gözlenmiştir (Patten ve Glick, 2000). Bakteri uygulamasının kuru ağırlığa olumlu etkisi ile ilgili bir çalışmada Soya Mısır rotasyon çalışmasında yapılmıştır ve çeşitli Bradyrhizobium izolatları kullanılmıştır. Bradyrhizobium USDA136 ve 532C izolatları misir köklerinde kuru madde oranlarını \% 8,45 ile \% 6,71 miktarlarında etkili olmuştur. Kullanılan izolatların mısır köklerinde yaşayan patojenlere karşı etkileri de incelenmiş ve 11 adet izolatın Sclerotinia sclerotium'un oluşmasını önlediği gözlenmiştir (Prevost ve ark., 2000).

\section{Sürgün (Gövde + Dal) Gelişimi}

Topraktan izole edilen 10 adet farkl rhizobakteri izolatının, EMA PLUS mikrobiyal gübre ve rhizobakteri uygulaması yapılmayan kontrol uygulaması ile karşılaştırıldığı denemede; rhizobakterilerin bitki boyu, sürgün yaş ağırlığı ve sürgün kuru ağırlığı özellikleri üzerine etkileri $\mathrm{p} \leq 0.05$ düzeyinde önemli bulunmuş ve elde edilen sonuçlar Çizelge 6'da özetlenmiştir. Çizelge 6'dan rhizobakteri izolatları içerisinde en fazla bitki boyu uzunluğu elde edilen uygulamaların \%49.53 artış ile ZHA246, \%48.99 artış ile ZHA215, \%48.36 artış ile ZHA017 ve \%47.09 artış ile ZHA090 olduğu ortaya çıkmıştır. 
Çizelge 6. Rhizobakteri izolatlarının kırmızı biberde sürgün gelişimi üzerine etkisi

\begin{tabular}{|c|c|c|c|c|c|c|}
\hline \multirow{2}{*}{$\begin{array}{c}\text { Rhizobakteri } \\
\text { İzolatları }\end{array}$} & \multicolumn{2}{|c|}{ Bitki Boyu } & \multicolumn{2}{|c|}{ Sürgün Yaş Ağırlığı } & \multicolumn{2}{|c|}{ Sürgün Kuru Ağırlığı } \\
\hline & $(\mathrm{cm}) *$ & $\%$ & (g/bitki)* & $\%$ & (g/bitki)* & $\%$ \\
\hline ZHA246 & $52.74 \mathrm{a}$ & 49.53 & $24.36 \mathrm{a}$ & 65.48 & $12.05 \mathrm{a}$ & 87.40 \\
\hline ZHA017 & $52.33 \mathrm{a}$ & 48.36 & $23.73 \mathrm{ab}$ & 61.20 & $11.77 \mathrm{a}$ & 83.04 \\
\hline ZHA287 & $49.66 \mathrm{ab}$ & 40.79 & $18.72 \mathrm{abc}$ & 27.17 & $9.84 \mathrm{ab}$ & 53.03 \\
\hline ZHA090 & $51.88 \mathrm{a}$ & 47.09 & $17.42 \mathrm{abc}$ & 18.34 & $9.48 \mathrm{ab}$ & 47.43 \\
\hline ZHA235 & 48.10ab & 36.37 & 19.09abc & 29.68 & $9.45 \mathrm{ab}$ & 46.96 \\
\hline ZHA215 & $52.55 \mathrm{a}$ & 48.99 & $19.14 \mathrm{abc}$ & 30.02 & $9.33 \mathrm{ab}$ & 45.10 \\
\hline ZHA308 & $39.61 \mathrm{bcd}$ & 12.30 & $18.15 \mathrm{abc}$ & 23.30 & $8.36 \mathrm{abc}$ & 30.01 \\
\hline ZHA212 & $46.22 \mathrm{abc}$ & 31.04 & 16.17abc & 9.85 & $8.23 \mathrm{abc}$ & 27.99 \\
\hline ZHA191 & $44.27 \mathrm{abcd}$ & 25.51 & $15.10 \mathrm{bc}$ & 2.58 & 7.92abc & 23.17 \\
\hline ZHA579 & 48.33ab & 37.02 & $14.99 \mathrm{bc}$ & 1.83 & $7.42 \mathrm{bc}$ & 15.39 \\
\hline KONTROL & $35.27 \mathrm{~cd}$ & & $14.72 \mathrm{c}$ & - & $6.43 \mathrm{bc}$ & - \\
\hline EMA PLUS & $33.33 \mathrm{~d}$ & 5.50 & $11.96 \mathrm{c}$ & 18.75 & $4.78 \mathrm{c}$ & 25.66 \\
\hline
\end{tabular}

$=\mathrm{p} \leq 0.05$ 'de ve ${ }^{* *}=\mathrm{p} \leq 0.01$ 'de önemli; öd =önemli değil; “\%” değerler kontrole göre farktır.

Farklı harfler ile gösterilen ortalamalar, Duncan Çoklu Karşılaştırma Testi'ne göre $\mathrm{p} \leq 0.05$ 'de önemlidir.

Sürgün yaş ağırlığına bakıldığında \%65.48 artış ile ZHA246 rhizobakteri izolatının en başarılı uygulama olduğu saptanmış; bunu \%61.20 artış ile ZHA017 takip ettiği belirlenmiş̧tir.

Araştırmada ZHA246 (\%87.40 artış) ve ZHA017 (\%83.04 artış) en fazla sürgün kuru ağırlığı elde edilen uygulamalar olmuştur. Sürgün özelliklerinde deneme konusu olan rhizobakteriler EMA PLUS mikrobiyal gübre ve rhizobakterisiz kontrol uygulamasina göre olumlu yönde etkiler göstermiştir. Rhizobakterilerin sürgün gelişimini teşvik edici etkileri benzer çalışmalara da konu olmuş yapılan bir çalışmada rhizobakterilerin sürgün uzunluğuna kontrole kiyasla önemli etkileri olduğu saptanmıştır (Banchio ve ark., 2008). Bir diğer çalışma ise Paenibacillus polymyxa izolatının domates bitkisinde yalnız yaprak alanı indeksi, bitki boyu ve klorofil miktarında artış yaşanmasıyla birlikte domates solgunluğu hastalığının etmeni Ralstonia solanacearum mücadelesinde de önemli ölçüde etkili olduğu gözlenmiştir (Deng ve ark., 2013). Bacillus megaterium, Bacillus sphaericus ve Bacillus polymyхa uygulayarak gerçekleştirilen çalışmada, bu bakterilerin ortamda bulunan kaya fosfatını etkileyerek bitki boyu ve ağırlığında artış meydana geldiği görülmüştür (De Freitas ve ark., 1997). Benzer çalışmalarda da bitkiler için kullanılan PGPR izolatlarının bitki büyümesini olumlu yönde etkilediği görülmüsşür (Wei ve ark., 1996; Khalid ve ark., 2003)

\section{Yaprak Gelişimi}

Kırmızı biberde farklı rhizobakteri izolatlarının yaprak sayısı, yaprak eni, yaprak boyu, yaprak yaş ağırlığı ve yaprak kuru ağırlığı üzerine etkileri istatistiksel analizler sonucunda $\mathrm{p} \leq 0.05$ düzeyinde önemli bulunmuş; elde edilen bulgular Çizelge 7'de verilmiştir. Çizelge 7 incelendiğinde yaprak sayısı üzerine en olumlu etkinin \%55.67 artış ile ZHA246 rhizobakteri izolatından alındığı belirlenmiştir. Yaprak enine bakıldığında en olumlu etki \%23.05 artış ile ZHA191 rhizobakterisinde görülmüştür.

Çizelge 7. Rhizobakteri izolatlarının kırmızı biberde yaprak gelişimi üzerine etkisi

\begin{tabular}{|c|c|c|c|c|c|c|c|c|c|c|}
\hline \multirow{2}{*}{$\begin{array}{c}\text { Rhizobakteri } \\
\text { İzolatları }\end{array}$} & \multicolumn{2}{|c|}{ Yaprak Sayısı } & \multicolumn{2}{|c|}{ Yaprak Eni } & \multicolumn{2}{|c|}{ Yaprak Boyu } & \multicolumn{2}{|c|}{$\begin{array}{c}\text { Yaprak Yaş } \\
\text { Ağırlığı }\end{array}$} & \multicolumn{2}{|c|}{$\begin{array}{c}\text { Yaprak Kuru } \\
\text { Ağırlığı }\end{array}$} \\
\hline & $($ adet/bitki)* & $\%$ & $(\mathrm{~mm} / \text { yaprak })^{*}$ & $\%$ & (mm/yaprak)* & $\%$ & $(\mathrm{~g} / \mathrm{bitki})^{*}$ & $\%$ & $(\mathrm{~g} / \mathrm{bitki})^{*}$ & $\%$ \\
\hline ZHA246 & $117.18 \mathrm{a}$ & 55.67 & $40.17 \mathrm{ab}$ & 17.97 & $101.97 \mathrm{a}$ & 9.94 & $39.72 \mathrm{a}$ & 96.14 & $9.08 \mathrm{a}$ & 57.63 \\
\hline ZHA215 & 92.08ab & 22.33 & $38.88 \mathrm{abc}$ & 14.18 & $102.33 \mathrm{a}$ & 10.32 & $31.97 \mathrm{ab}$ & 57.87 & $7.56 \mathrm{ab}$ & 31.25 \\
\hline ZHA287 & $91.88 \mathrm{ab}$ & 22.06 & $37.22 \mathrm{abc}$ & 9.30 & $94.75 \mathrm{a}$ & 2.15 & $28.80 \mathrm{ab}$ & 42.22 & 7.51ab & 30.38 \\
\hline ZHA191 & $101.44 \mathrm{ab}$ & 34.76 & $41.90 \mathrm{a}$ & 23.05 & $105.99 \mathrm{a}$ & 14.27 & $30.82 \mathrm{ab}$ & 52.19 & $6.84 a b$ & 18.75 \\
\hline ZHA017 & 95.99ab & 27.52 & $37.87 \mathrm{abc}$ & 11.21 & $95.18 \mathrm{a}$ & 2.61 & $31.17 \mathrm{ab}$ & 53.92 & $6.65 a b$ & 15.45 \\
\hline ZHA235 & 91.99ab & 22.21 & $40.67 \mathrm{ab}$ & 19.44 & $107.67 \mathrm{a}$ & 16.08 & $27.04 \mathrm{ab}$ & 33.53 & $6.63 \mathrm{ab}$ & 15.10 \\
\hline ZHA579 & 91.88ab & 22.06 & $37.76 \mathrm{abc}$ & 10.89 & $97.53 \mathrm{a}$ & 5.15 & $25.59 \mathrm{~b}$ & 26.37 & $5.98 b$ & 3.81 \\
\hline ZHA212 & $83.10 \mathrm{ab}$ & 10.40 & $35.56 \mathrm{bc}$ & 4.43 & $103.20 \mathrm{a}$ & 11.26 & $25.79 \mathrm{ab}$ & 27.35 & $5.74 \mathrm{~b}$ & -0.34 \\
\hline ZHA308 & 79.33ab & 5.39 & $35.71 \mathrm{bc}$ & 4.87 & $96.23 \mathrm{a}$ & 3.75 & $19.83 \mathrm{~b}$ & -2.07 & $5.27 \mathrm{~b}$ & -8.50 \\
\hline ZHA090 & 86.33ab & 14.69 & $37.26 a b c$ & 9.42 & $99.00 \mathrm{a}$ & 6.73 & $26.84 \mathrm{~b}$ & 32.54 & $5.19 b$ & -9.89 \\
\hline KONTROL & $75.27 \mathrm{~b}$ & - & $34.05 \mathrm{c}$ & - & $92.75 a$ & & $20.25 \mathrm{~b}$ & & $5.76 \mathrm{~b}$ & \\
\hline EMA PLUS & $88.89 \mathrm{~b}$ & 18.09 & $29.13 \mathrm{~d}$ & 14.44 & $77.46 \mathrm{~b}$ & 16.48 & $24.72 \mathrm{~b}$ & 22.07 & $4.87 \mathrm{~b}$ & 15.45 \\
\hline
\end{tabular}

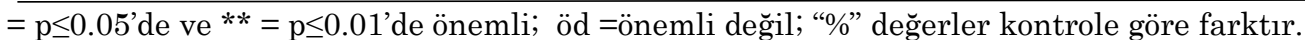

Farklı harfler ile gösterilen ortalamalar, Duncan Çoklu Karşılaştırma Testi’ne göre $\mathrm{p} \leq 0.05$ 'de önemlidir. 


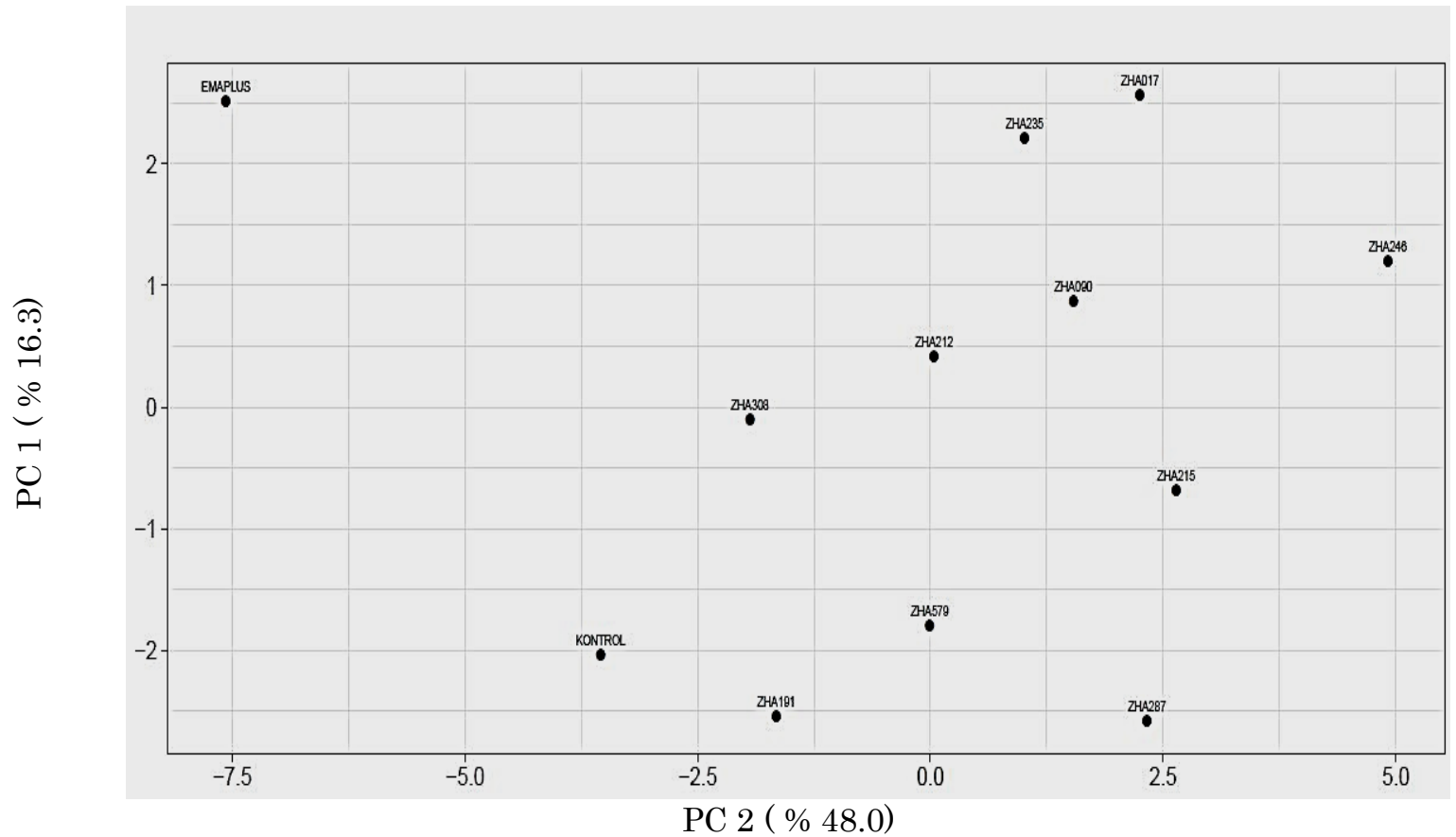

Şekil 1. Rhizobakterilerin incelenen tüm özelliklere göre Temel Bileşenler Analizi (PCA) sonucuna göre dağılımı

ZHA191 uygulamasını aynı istatistiki grubun birer üyesi olan \%19.44 artış ile ZHA235 ve \%17.97 artış ile ZHA246 uygulamaları izlemişlerdir. Denemede yer alan tüm rhizobakteri izolatlarının da kontrol uygulamalarından daha geniş yaprak oluşumuna neden oldukları anlaşılmıştır. Yaprak boyunda ise en düşük değeri veren EMA PLUS dışındaki tüm uygulamaların daha uzun yaprak oluşumuna neden oldukları anlaşılmıştır. Rhizobakteri izolatlarının yaprak yaş ağırlığına en olumlu etki \%96.14 artış ile ZHA246 rhizobakterisinde gözlemlenmiştir. En yüksek yaprak kuru ağırlığı değerine \%57.63 artış ile ZHA246 rhizobakteri izolatında ulaşılmıştır. Yapılan önceki bir çalışmada Paenibacillus polymyxa izolatının domates bitkisinde bitki boyu, klorofil miktarında yükselme, yaprak alanı indeksi ve bitki boyunda artışlar olmasına sebep olmakla birlikte domates solgunluğu hastallğını etmeni Ralstonia solanacearum mücadelesinde önemli ölçüde etkili olduklarını göstermişlerdir (Deng ve ark., 2013).

\section{Özelliklerin Birlikte Değerlendirilmesi}

Denemeye konu olan rhizobakterilerin tüm incelenen özelliklere göre birbirlerine olan farklılıklarını daha açık bir şekilde ortaya koymak amacıyla temel bileşenler analizi yönteminden yararlanılmıştır (Şekil 1). Şekil 1'de, bulundukları yer bakımından rhizobakteriler arasında birbirinden farklılıklar olduğu görülebilmektedir. Buna göre denemede incelenen tüm özelliklere göre ortaya çıkan rhizobakteri gruplarının sıfir eksenlerinde bulundukları yerler değişmekte, grafiğin sağ üst kısmına gidildikçe ZHA246 ve ZHA017'nin diğerlerine göre öne çıktığı; ZHA235'in de hemen bunların arkasında yer alarak dikkat çektiği söylenebilir. ZHA090 ve ZHA212 ise daha sonraki sıralardadir.

Kontrol ve kontrole yakın olan ZHA191, ZHA579 ve ZHA308 yanında EMA PLUS'un zit konumlariyla; diğer rhizobakteriler kadar kullanılma potansiyellerinin bulunmadığı ortaya çıkmıştır.

\section{SONUÇ}

Sonuç olarak mikrobiyal gübre olarak 10 farklı rhizobakteri izolatının kullanılabilme potansiyelini ortaya koymak üzere yapılan bu araştırmada; deneme konusu olan rhizobakterilerin tümünün kontrolleri ile karşılaştırıldığında meyve tohum yaş ağırlığı, meyve tohum kuru ağırlı̆̆ı, meyve eti yaş ağırlığı, meyve eti kuru ağırlığı, meyve yaş ağırlığı ve kök boyu dışındaki tüm özellikler üzerine olumlu etkileri olduğu ortaya konulmuştur.

Araştırmada tüm incelenen özellikler ele alınarak öne çıkan rhizobakterileri ortaya koymak üzere yapılan temel bileşenler analizi ZHA246 ve ZHA017'nin amaca uygun oldukları anlaşılmıştır. ZHA235'te dikkate değer diğer rhizobakteri olmuştur. Kırmızı biberde verim ve diğer bitkisel özellikler üzerine kontrolle aynı grupta gösterilebilecek ZHA191, ZHA579 ve ZHA308 yanında EMA PLUS'ın etkilerinin ise diğer uygulamalar kadar olmadığı belirlenmiştir.

\section{TEŞEKKÜR}

Bu çalışma Danışmanlığı Prof.Dr İrfan Ersin AKINCI ve Eş Danışmanlığı Dr. Öğr. Üyesi Mustafa KÜSEK tarafından yürütülen Ümran TELEK'in yüksek lisans tezinin özetidir. 


\section{KAYNAKLAR}

Aksoy U 1999. Ekolojik Tarımdaki Gelişmeler, Ekolojik Tarım, Ekolojik Tarım Organizasyonu Derneği, Emre Basımevi, İzmir. 30-35s.

Anonim 2017. Clustvis: a Web Tool For Visualizing Clustering of Multivariate Data (BETA). https://biit.cs.ut.ee/clustvis

Asghar H N, Zahir, Z A, Arshad M 2004. Screening Rhizobacteria for Improving the Growth, Yield ve Oil Content for Canola (Brassica napus L.).Australian Journal of Agricultural Research, 55 (2):187-194.

Banchio, E, Bogino PC, Zygadio J, Giordano W 2008. Plant Growth Promoting Rhizobacteria Improve Growth ve Essential Oil Yield in Origanum majorana L. Biochemical Systematics ve Ecology, 36: 766-771.

Bayrak D, Ökmen G 2014. Bitki Gelişimini Uyaran Kök Bakterileri. Anadolu Doğa Bilimleri Dergisi, 5(1): 1-13.

Çakmakçı R, Dönmez MF, Canpolat M, Şahin F 2005. Sera ve Farklı Tarla Koşullarında Bitki Gelişimini Teşfik Edici Bakterilerin Bitki Gelişimi ve Toprak Özelliklerine Etkisi. Türkiye VI. Tarla Bitkileri Kongresi Antalya, Cilt-1, 45-50s.

De Freitas JR, Banerjee MR, Germida .J 1997. Phosphate-Solubilizing Rhizobacteria Enhance the Growth ve Yield but not Phosphorus Uptake of Canola (Brassica napus L). Biol Fertil Soils, 24: 358-364.

Ertürk Y, Ercişli S, Çakmakçı R 2012. Yield ve Growth Response of Strawberry (Fragaria X ananassa Duch.) to Plant Growth Promoting Rhizobacteria Inoculation. Journal of Plant Nutrition 35: 817-826.

Eşiyok D 2012. Kışlık ve Yazlık Sebze Yetiştiriciliği. Ege Üniversitesi, Ziraat Fakültesi Bahçe Bitkileri Bölümü, 410s.

Higa T, Parr J F 1994. Beneficial ve Effective Microorganisms for a Sustainable Agriculture ve Environment. International Nature Farming Research Center Atami, Japan. 25s.

İmriz G, Özdemir F, Topal İ, Ercan B, Taş MN, Yakışır E, Okur O 2014. Bitkisel Üretimde Bitki Gelişimini Teşvik Eden Rizobakteri (PGPR)'ler ve Etki Mekanizmaları. Elektronik Mikrobiyoloji Dergisi, 12(2): 1-19

Jeyarajan R, Nakkeeran S 2000. Exploitation of Microorganisms ve Viruses as Biocontrol Agents for Crop Disease Mangement. In: Biocontrol Potential ve their Exploitation in Sustainable agriculture. Upadhyay (Ed.). 95-116s. Kluwer Academic/ Plenum Publishers, USA.

Khalid A, Arshad M, Zahir ZA 2003. Growth Yield Response of Wheat to Inoculation With Auxin Producing Plant Growth Promoting Rhizobacteria. Pakistan Journal of Botany, 35(4):483-498.
Kleopper JW, Schroth MN 1978. Plant Growth Promoting Rhizobacteria on Radishes. In Proceedings of the Fourth International Conference on Plant Pathogenic Bacteria, Vol. 2 pp 879-882.

Meral N, Çiftçi CY, Ünver S 1998. Bakteri Aşılaması ve Değişik Azot Dozlarının Nohut (Cicer arietinum L.)' un Verim ve Verim Öğelerine Etkileri. Tarla Bitkileri Merkez Araştırma Enstitüsü Dergisi 7 (1): 44-59.

Mirik M, Aysan Y, Çınar Ö 2008. Biber Bakteriyel Leke Hastalığına Karşı Bacillus İzolatlarıyla Biyolojik Mücadele. (32): 381-390.

Öztekin GB, Tüzel Y, Ece M 2015. Azot Tutucu Bakteri Kullanımının Sera Domates Yetiştiriciliğinde Bitki Gelişimi, Verim ve Meyve Kalitesi Üzerine Etkileri, Iğdır Üniversitesi, Fen Bilimleri Enstitüsü Dergisi, 5(1): 21-27.

Patten CL, Glick BR 2000. Isolation ve Characterization of Indole Acetic Acid Biosynthesis Genes from Plant Growth Promoting Bacteria. Fifth International PGPR Workshop, 29 October - 3 November, 2000, Cordoba, Argentina.

Potts M 1994. Desiccation Tolerance of Prokaryotes. Microbiology Reviews, 58, 755-805s.

Prevost D, Saddiki S, Antoun H 2000. Growth ve Mineral Nutrition of Corn Inoculated with Effective Strains of Bradyrhizobium japonicum. Fifth International PGPR Workshop, 29 October - 3 November, 2000, CordobaArgentina.

Romerio RS 2000. Preliminary Results on PGPR Research at the Universidade Federal de Viçosa, Brazil. Fifth International PGPR Workshop, 29 October - 3 November, 2000, Cordoba-Argentina. 15 (2) $2005,87-103 \mathrm{~s}$.

Svehya V, Ali SKZ, Grover M, Reddy G, Venkateswarlu B 2009. Alleviation Of Drought Stress Effects In Sunflower Seedlings By The Exopolysaccharides Producing Pseudomonas putida Strain GAP-P45. Biology ve Fertility of Soils, $46: 17-26$.

Uslu A 2006. Bazı Baklagil Bitkilerinde Bitki Gelişimini Uyaran Kökbakterileri (PGPR) ile Verimin Artırılması. Ege Üniversitesi, Fen Bilimleri Enstitüsü, Bitki Koruma Anabilim Dalı, Yüksek Lisans Tezi, 95s.

Vinale FR, Scala F, Ghisalberti EL, Lorito M, Sivasithamparam K 2006. Major Secondary School Metabolites Produced by Two Commercial Trichoderma Strains Active Againts Different Phytopatholgens Lett Appl. Microbiol. 43: 143-148.

Wei G, Kloepper JW, Tüzün S 1996. Induced Systemic Resistance to Cucumber Diseases ve Increased Plant Growth by Plant Growth-Promoting Rhizobacteria Under Field Conditions. Phytopathology 86:221-224 